\title{
DESIGN AND COMPARISON OF A RESIDENTIAL BUILDING (G+10) FOR SEISMIC FORCES USING THE CODES: IS1893, EURO CODE8, ASCE 7-10 AND BRITISH CODE
}

\author{
S.Karthiga ${ }^{1}$, Hanna Elza Titus ${ }^{2}$, Reetwiz Raj Hazarika ${ }^{3}$, Mohamed Harrish ${ }^{4}$ \\ ${ }^{1}$ Assistant Professor, Department of Civil Engineering, SRM University, Chennai, India \\ ${ }^{2}$ Student, Department Of Civil Engineering, SRM University, Chennai, India \\ ${ }^{3}$ Student, Department Of Civil Engineering, SRM University, Chennai, India \\ ${ }^{4}$ Student, Department Of Civil Engineering, SRM University, Chennai, India
}

\begin{abstract}
Earthquakes take a huge toll on life and property. Since the effect of seismic forces on structures is quite significant, it is important that the design of the structures must be done in the best possible way to take into account these effects and thereby aiming for an adequate structural response. Different international seismic codes differ significantly in parameters specified. With the variations in parameters the performance of the building varies. Hence, it is necessary to do a comparative study so as to conclude which building will perform better.
\end{abstract}

This paper presents with the analysis and design of a G+10 for seismic forces using four international building standardsIS1893, Euro code 8, ASCE7-10 and the British Codes. The analysis of the building was done using STAAD.Pro.V8i. The building was then designed as per the specified codes. Once the design was completed a pushover analysis was done in SAP2000 to check the seismic performance of the building. A comparative study between the design and the seismic performance of the building was done.

Keywords: Seismic forces, Seismic Standard, Seismic performance, Comparative Analysis.

\section{INTRODUCTION}

Earthquakes take a huge toll on life and property. Seismic design provisions are incorporated to increase the building integrity and ensure the future safety of communities. The existing codes differ significantly in specifying the limits on various control parameters; and if a building is designed for a given seismic hazard, using different seismic design codes, it is expected that the seismic performance of a building will vary significantly. Due to this reason, there is a need to conduct comparative studies that may lead to the harmonization of different international seismic design codes. This establishes also a crucial step in the process of evolution of the next generation of design codes.

In this project, a $\mathrm{G}+10$ building is planned and analysed. The design is carried out using four International Seismic Standards- IS 1893 -Criteria for earthquake resistant design of structures Part 1, Eurocode 8- Design of structures for Earthquake resistance Part 1, ASCE 7-10- Minimum Design loads for buildings and other structures, British code. The performance of the building will be checked using pushover analysis.

\subsection{Research Objectives}

The objectives of the paper are stated below:

- To plan a $\mathrm{G}+10$ building.
- To analyse the building

- To design the $\mathrm{G}+10$ building using the four international seismic standards- IS 1893 -Criteria for earthquake resistant design of structures Part 1, EUROCODE 8- Design of structures for Earthquake resistance Part 1, ASCE 7-10Minimum Design loads for buildings and other structures, British code-UK Annex To Euro Code 8.

- $\quad$ To check the performance of the designed building by carrying out pushover analysis using SAP2000.

\subsection{Methodology}

The basic methodology followed during the course of the study is as follows. Firstly, a G+10 building was planned. The seismic definitions for each of the four international standards were specified and the building was modeled and analysed in STAAD.Pro.V8i. The main members of the building- columns and beams were designed as per the respective standards. Once the design was completed, the seismic performance of the building was checked by doing a pushover analysis on the building. The capacity curve was obtained which gives the displacement of the building against base shear values. 


\section{PLANNING}

This section comprises of the details of the $\mathrm{G}+10$ building. The building was planned and designed as per the NBC provisions. The plan of the ground floor of the building is given in Fig.1.

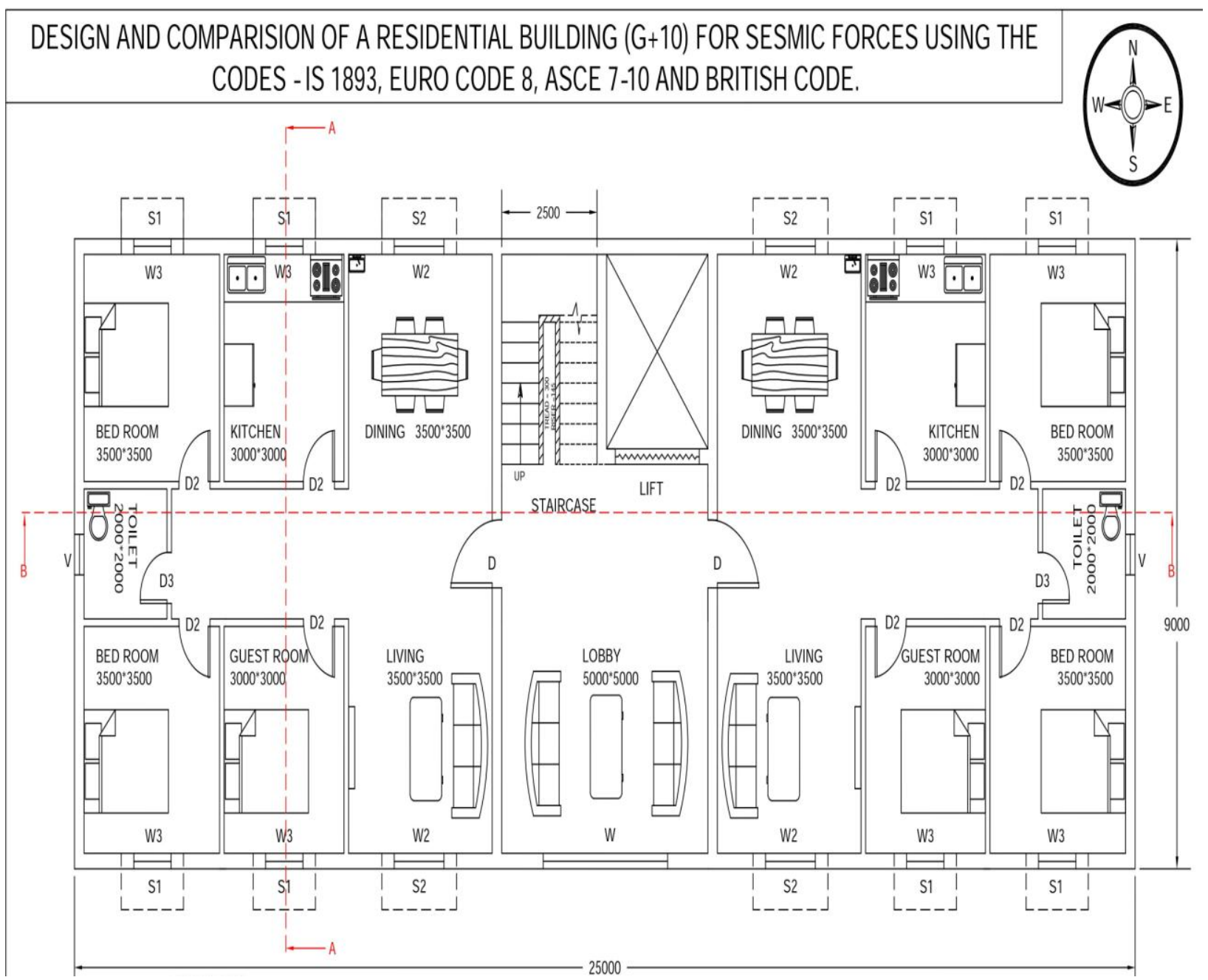

Fig-1: Ground floor plan of the building.

The building description has been listed below in Table 1 .

Table 1- Building Description

\begin{tabular}{|l|l|}
\hline Building Type & Reinforced Concrete Frame \\
\hline Usage & Residential Apartment \\
\hline Number of stories & Ground +10 \\
\hline Plan dimensions & $25 \mathrm{~m} \times 9 \mathrm{~m}$ \\
\hline Building Height & $33 \mathrm{~m}$ \\
\hline
\end{tabular}

The grade of concrete used is M35 and the reinforcing steel used is Fe315.

\section{SEISMIC PARAMETERS}

The site for the building was chosen to have medium soil. The seismic parameters were defined as per the respective codes: IS1893, ASCE 7-10, EuroCode8 and the UK Annex to EuroCode8.
As per the Indian standard, the zone factor was taken as 0.16 for zone III. The rock and soil site factor is taken as 2 . A damping ratio of $5 \%$ is taken and the fundamental natural period of 1.03 . The importance factor is 1 .

The equivalent values for the other codes were also specified. Euro Code stated the equivalent as ground $\mathrm{C}$ having a damping ratio of $5 \%$ and importance factor 1 . The horizontal elastic response spectrum was taken as 3.739 . The elastic displacement response spectrum was 0.1011, vertical elastic response spectrum of 1.562 , design ground displacement of 0.033 .

As per ASCE 7-10, the equivalent values were taken. The importance factor was 1 on a site class D. The risk category was II. Damping ratio was $5 \%$. The period in $\mathrm{X}$ and $\mathrm{Y}$ direction is calculated as 1.033 . The spectral acceleration was calculated as 0.467 and 0.267 . The design response spectrum was 0.258 . 
As per the UK Annex to Euro Code 8, the equivalent parameters were defined. The site class is $\mathrm{C}$. The damping ratio was $5 \%$. The elastic response spectrum was calculated as 0.063 . The site coefficients $F_{a}$ and $F_{v}$ are 1 and 1.3 respectively.

\section{ANALYSIS AND DESIGN}

The building was modeled in STAAD.Pro.V8i and the various loads acting on the building was applied. The response spectrum was defined in the software as per the calculations. The building was then designed in STAAD.Pro.V8i.

The manual design for the critical columns and beams were done in accordance to the respective codes. The codes used in the design were IS456:2000, SP 16, Euro Code 2:1992, ASCE 7-10, BS 8110.

The comparison between the design of beams has been listed in Table 2 below.

Table 2- Beam Reinforcement Details of all Four Codes

\begin{tabular}{|c|c|c|c|c|c|}
\hline $\begin{array}{l}\mathbf{S} . \\
\mathbf{N} \\
\mathbf{0}\end{array}$ & $\begin{array}{l}\text { Parame } \\
\text { ters }\end{array}$ & $\begin{array}{l}\text { India } \\
\text { n } \\
\text { Code }\end{array}$ & $\begin{array}{l}\text { Euro } \\
\text { Code }\end{array}$ & $\begin{array}{l}\text { Americ } \\
\text { an } \\
\text { Code }\end{array}$ & $\begin{array}{l}\text { Britis } \\
\text { h } \\
\text { Code }\end{array}$ \\
\hline 1. & Size & $\begin{array}{l}300 \\
\times 300 \\
\mathrm{~mm}\end{array}$ & $\begin{array}{l}300 \times 3 \\
00 \\
\mathrm{~mm}\end{array}$ & $\begin{array}{l}300 \times 30 \\
0 \mathrm{~mm}\end{array}$ & $\begin{array}{l}300 \times 3 \\
00 \\
\mathrm{~mm}\end{array}$ \\
\hline 2. & $\begin{array}{l}\text { Area of } \\
\text { steel } \\
\text { required }\end{array}$ & $\begin{array}{l}1910 \\
\mathrm{~mm}^{2}\end{array}$ & $\begin{array}{l}1005 \\
\mathrm{~mm}^{2}\end{array}$ & $\begin{array}{l}1360 \\
\mathrm{~mm}^{2}\end{array}$ & $\begin{array}{l}1884 \\
\mathrm{~mm}^{2}\end{array}$ \\
\hline 3. & $\begin{array}{l}\text { Number } \\
\text { of bars }\end{array}$ & 4 & 5 & 3 & 6 \\
\hline 4. & $\begin{array}{l}\text { Diamete } \\
\mathrm{r} \text { of bars }\end{array}$ & $\begin{array}{l}25 \\
\mathrm{~mm}\end{array}$ & $\begin{array}{l}16 \\
\mathrm{~mm}\end{array}$ & $24 \mathrm{~mm}$ & $\begin{array}{l}20 \\
\mathrm{~mm}\end{array}$ \\
\hline 5. & $\begin{array}{l}\text { Spacing } \\
\text { of bars }\end{array}$ & $\begin{array}{l}188 \\
\mathrm{~mm}\end{array}$ & $\begin{array}{l}80 \\
\mathrm{~mm}\end{array}$ & $74 \mathrm{~mm}$ & $\begin{array}{l}80 \\
\mathrm{~mm}\end{array}$ \\
\hline 6. & $\begin{array}{l}\text { Stirrups } \\
\text { spacing }\end{array}$ & $\begin{array}{l}8 \mathrm{~mm} \\
\text { dia@ } \\
180 \\
\mathrm{~mm} \\
\mathrm{c} / \mathrm{c}\end{array}$ & $\begin{array}{l}10 \\
\mathrm{~mm} \\
\text { dia @ } \\
225 \\
\mathrm{~mm} \\
\mathrm{c} / \mathrm{c}\end{array}$ & $\begin{array}{l}12 \mathrm{~mm} \\
\mathrm{dia} @ \\
225 \\
\mathrm{~mm} \mathrm{c} / \mathrm{c}\end{array}$ & $\begin{array}{l}10 \\
\mathrm{~mm} \\
\text { dia } \\
@ 300 \\
\mathrm{~mm} \\
\mathrm{c} / \mathrm{c}\end{array}$ \\
\hline
\end{tabular}

The design of the column was also undertaken in accordance with the respective codes. The comparison of the design of the columns has been listed below in Table 3 .

Table 3- Column Reinforcement Details of all the four

\begin{tabular}{|l|l|l|l|l|l|}
\hline $\begin{array}{l}\text { S.N } \\
\text { o }\end{array}$ & $\begin{array}{l}\text { Paramete } \\
\text { rs }\end{array}$ & $\begin{array}{l}\text { Indian } \\
\text { Code }\end{array}$ & $\begin{array}{l}\text { Euro } \\
\text { Code }\end{array}$ & $\begin{array}{l}\text { Americ } \\
\text { an Code }\end{array}$ & $\begin{array}{l}\text { British } \\
\text { Code }\end{array}$ \\
\hline 1. & Size & $\begin{array}{l}500 \times 5 \\
00 \mathrm{~mm}\end{array}$ & $\begin{array}{l}300 \times 3 \\
00 \mathrm{~mm}\end{array}$ & $\begin{array}{l}300 \times 300 \\
\mathrm{~mm}\end{array}$ & $\begin{array}{l}300 \times 3 \\
00 \mathrm{~mm}\end{array}$ \\
\hline 2. & $\begin{array}{l}\text { Area of } \\
\text { steel }\end{array}$ & $\begin{array}{l}\mathbf{5 6 8 7 . 5} \\
\mathbf{m m}^{2}\end{array}$ & $\begin{array}{l}2277.1 \\
1 \mathrm{~mm}^{2}\end{array}$ & $\begin{array}{l}2510 \\
\mathrm{~mm}^{2}\end{array}$ & $\begin{array}{l}2430 \\
\mathrm{~mm}^{2}\end{array}$ \\
\hline 3. & $\begin{array}{l}\text { Number } \\
\text { of bars }\end{array}$ & 12 & 8 & 8 & 8 \\
\hline 4. & Diameter & $25 \mathrm{~mm}$ & $20 \mathrm{~mm}$ & $20 \mathrm{~mm}$ & $20 \mathrm{~mm}$ \\
\hline
\end{tabular}

\begin{tabular}{|l|l|l|l|l|l|}
\hline & of bars & & & & \\
\hline 5. & $\begin{array}{l}\text { Spacing } \\
\text { of bars }\end{array}$ & $\begin{array}{l}125 \\
\mathrm{~mm}\end{array}$ & $90 \mathrm{~mm}$ & $62.5 \mathrm{~mm}$ & $\begin{array}{l}100 \\
\mathrm{~mm}\end{array}$ \\
\hline 6. & $\begin{array}{l}\text { Ties } \\
\text { spacing }\end{array}$ & $\begin{array}{l}8 \mathrm{~mm} \\
\text { dia }\end{array}$ & $\begin{array}{l}10 \mathrm{~mm} \\
\text { dia }\end{array}$ & $\begin{array}{l}12 \mathrm{~mm} \\
\text { dia 225 } \\
\text { mm c/c }\end{array}$ & $\begin{array}{l}820 \\
\text { dia } \\
300 \\
\text { mm c/c } \\
\text { mm c/c }\end{array}$ \\
\hline
\end{tabular}

The maximum values of the area of steel have been highlighted in the tables above. The columns and beams designed as per Indian standards require the maximum area of steel whereas those designed in accordance with Euro Standards require the minimum.

\section{PUSHOVER ANALYSIS}

The design of the building was completed using all the mentioned four codes- Indian, Euro, American and British Code. Once the design was completed, the performance of the building was checked using pushover analysis using SAP 2000. The pushover analysis curves were obtained for all the four codes.

Non-linear static analysis or pushover analysis is being considered within modern seismic codes, both for design of new structures and for assessment of existing ones. A pattern of forces is applied to a structural model that includes non-linear properties and the total force is plotted against the roof displacement to define a capacity curve.

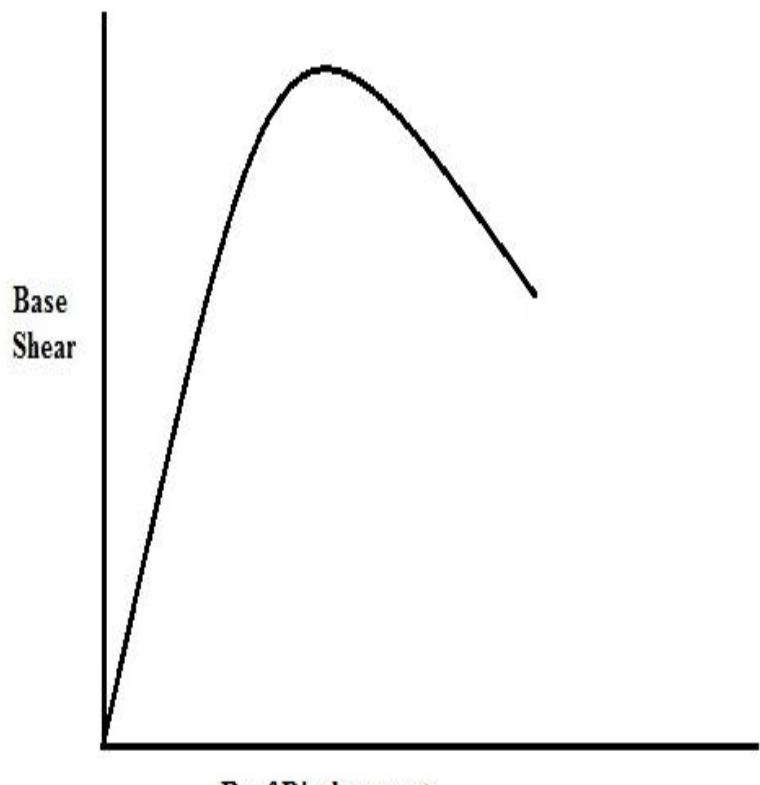

Roof Displacement

Fig-2: Pushover Analysis- Graph

The capacity spectrum is obtained from SAP 2000. The spectrum indicates the increase in displacement with increase in Base shear.The capacity spectrum of the four codes have been given below in Fig-3, Fig-4, Fig-5 and Fig6. 


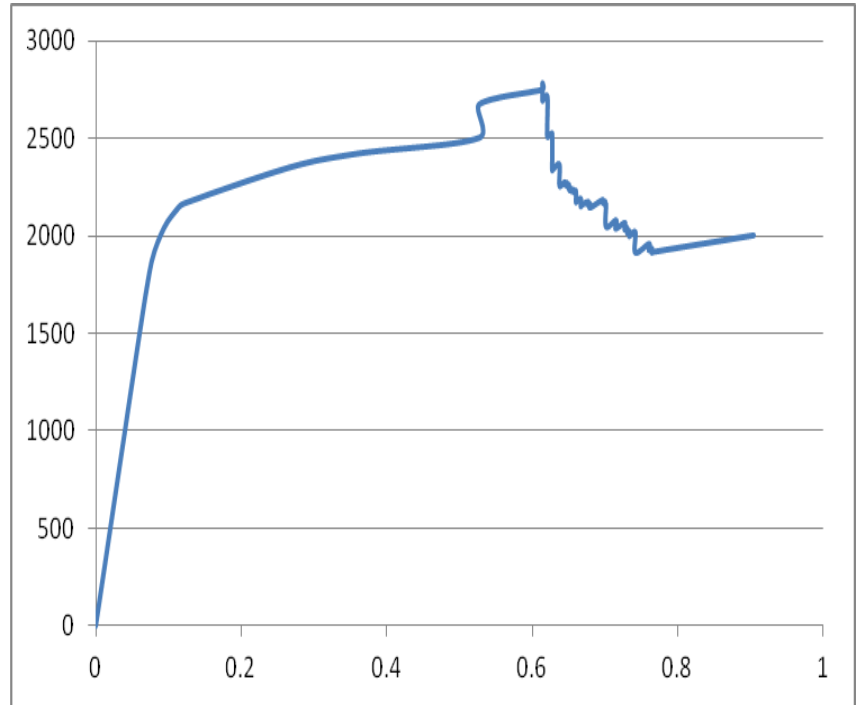

Fig-3: Capacty Spectrum- Indian Code

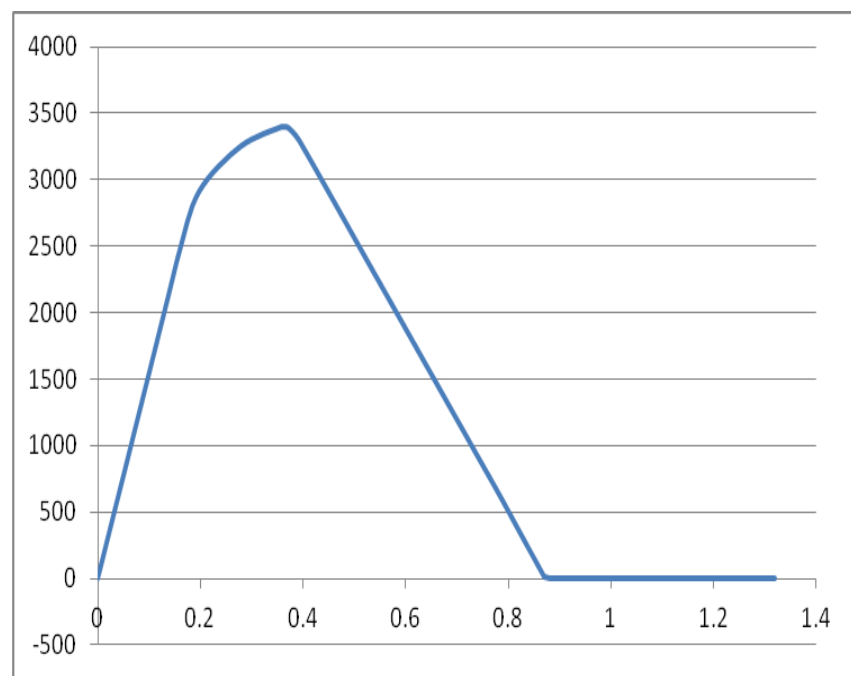

Fig-4: Capacity Spectrum- Euro Code

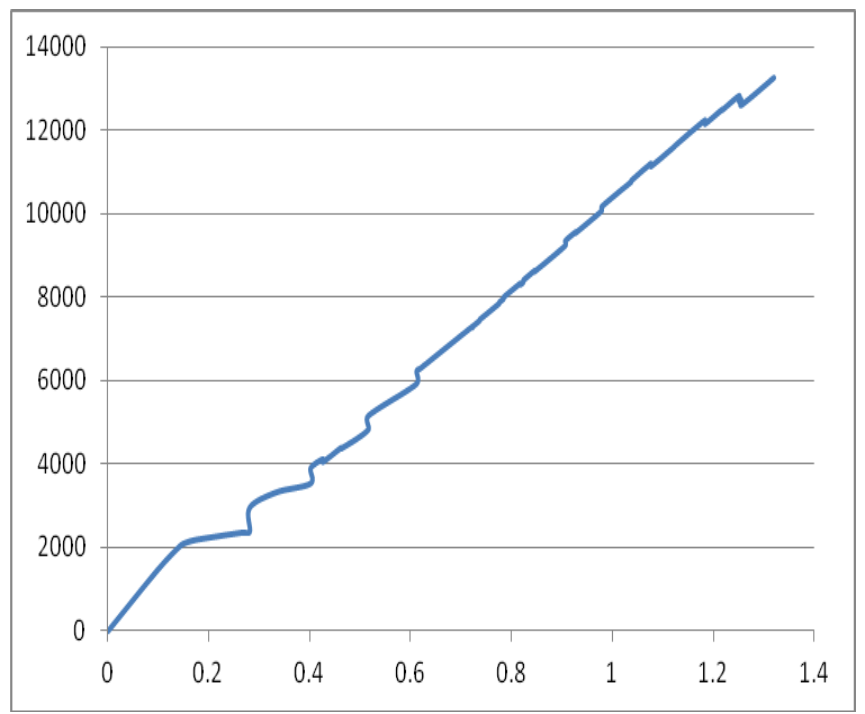

Fig-5: Capacity Spectrum- American Code

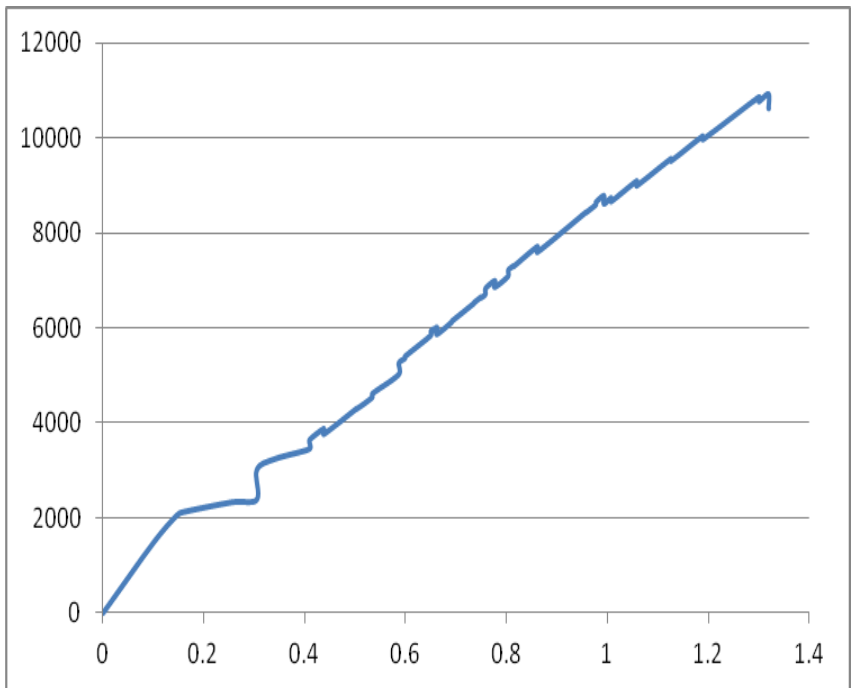

Fig-6: Capacity Spectrum- British Code

From the curves, the values of base shear and displacement have been obtained. The values have been plotted in the table below in Table IV

Table 4:

\begin{tabular}{|l|l|l|}
\hline \multirow{2}{*}{ Code } & \multicolumn{2}{|l|}{ Performance Point } \\
\cline { 2 - 3 } & Shear V in kN & $\begin{array}{l}\text { Displacement d } \\
\text { in m }\end{array}$ \\
\hline $\begin{array}{l}\text { Indian } \\
\text { Code }\end{array}$ & 2120.341 & 0.109 \\
\hline Euro Code & 2056.472 & 0.133 \\
\hline $\begin{array}{l}\text { American } \\
\text { Code }\end{array}$ & 1884.974 & 0.131 \\
\hline $\begin{array}{l}\text { British } \\
\text { Code }\end{array}$ & 1860.699 & 0.130 \\
\hline
\end{tabular}

The chart showing the comparision of the base shear values and displacement values of the four codes is given in Fig-7 and Fig-8.

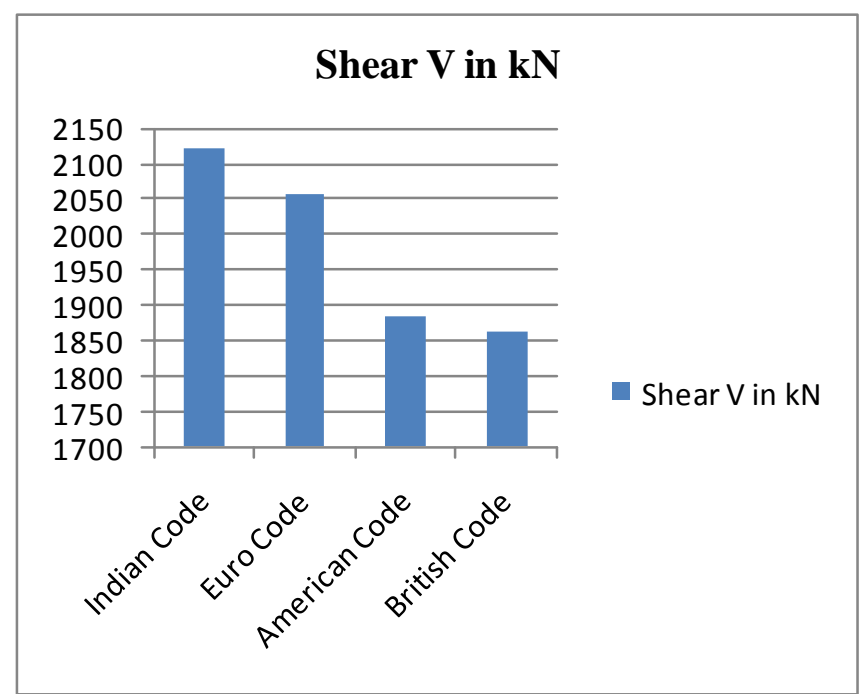

Fig-7: Graph showing the variation in Base Shear values for the four standards. 


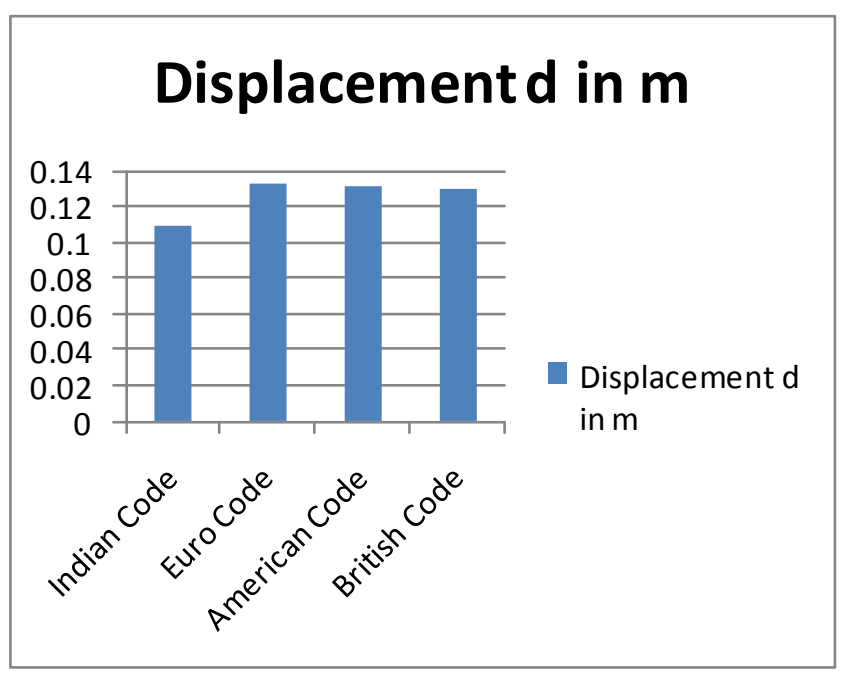

Fig-8: Graph showing the variation in Displacement for the four standards.

From the results obtained, we can conclude that the Indian standards gives the highest value of base shear which is $2120.341 \mathrm{kN}$ and the British standards give the minimum value which is $1860.699 \mathrm{kN}$. The displacement results were also compared and it is observed that the displacement obtained from Euro code was the maximum which is $0.133 \mathrm{~m}$ and that obtained for Indian Standards was the minimum, $0.109 \mathrm{~m}$.

\section{CONCULSION AND RESULT DISCUSSION}

The analysis and design of the $\mathrm{G}+10$ building was done using software as well as manually. A comparative study was done on the design of the building to check which was the most economical. It was concluded that the Euro standards served to be the most economical design and the Indian Standards were the least economical.

- A pushover analysis was performed on the building using SAP2000 to check the performance of the building. Base shear and displacement values were obtained and a graph was plotted showing the variations.

- From the pushover analysis results it can be concluded that the Indian standards has the maximum shear value. As compared to Indian Standards the euro standards has a percentage decrease of $3.05 \%$, American standards a decrease of $11.10 \%$ and British standards a decrease of $12.24 \%$

- From the displacement values it can be concluded that Indian Standards undergo minimum displacement. As compared to the Indian Standards Euro Standards has a percentage increase of $22 \%$, American Standards an increase of $20 \%$ and British Standards an increase of $19 \%$. It can thus be inferred that building designed according to the Indian standards are more rigid and thus it attracts more seismic forces.

\section{REFERENCES}

[1]. Vijay Namdev Khose (2012), Comparative Seismic performance of RC Frame Buildings Designed for ASCE 7 and IS 1893.

[2]. Hugo Pereira Lopes, Comparison between Eurocode8 and RSA/REBAP seismic design of reinforced concrete structures.

[3]. S.H.C.Santos, Comparative study of codes for seismic design of structures.

[4]. IS1893(2002), Criteria for earthquake resistant design of structures.

[5]. IS 875 Part 2- Design Loads for buildings and structures.

[6]. IS 456. (2000). Plain reinforced concrete-code of practice, Bureau of Indian Standards, New Delhi, India.

[7]. SP 16 Design aids for Reinforced concrete to IS 456:1978.

[8]. Euro code 8 design of structures for earthquake resistance.

[9]. Euro Code 2 design of concrete structures.

[10]. ASCE 7-10 Design for buildings and other structures

[11]. UK National Annex to EuroCode8: Design Of structures for earthquake resistance.

[12]. BS 6399:1-Code of practices for dead and imposed loads.

[13] BS8110- Design of reinforced and prestresssed concrete structures. 